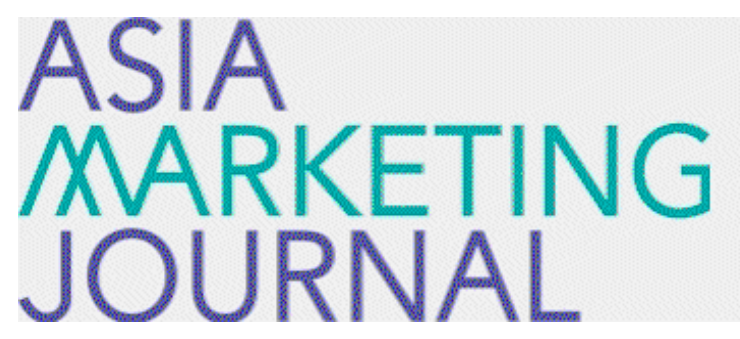

ASIA MARKETING JOURNAL

Volume 12 | Issue 2

Article 1

7-30-2010

\title{
온라인 구전과 영화 매출 간 상호영향에 관한 연구
}

Jung Ho Bae

Bum Jun Shim

Byung Do Kim

Follow this and additional works at: https://amj.kma.re.kr/journal

Part of the Marketing Commons

\section{Recommended Citation}

Bae, Jung Ho; Shim, Bum Jun; and Kim, Byung Do (2010) "돈라인 구전과 영화 매출 간 상호영향에 관한 연 구," Asia Marketing Journal: Vol. 12 : Iss. 2 , Article 1.

Available at: https://doi.org/10.53728/2765-6500.1253

This Article is brought to you for free and open access by Asia Marketing Journal. It has been accepted for inclusion in Asia Marketing Journal by an authorized editor of Asia Marketing Journal. 


\title{
온라인 구전과 영화 매출 간 상호영향에 관한 연구: 한국 영화 산업을 중심으로
}

\section{Simultaneous Effect between eWOM and Revenues: \\ Korea Movie Industry}

\author{
배 정 호(Bae, Jungho)** \\ 심 범 준(Shim, Bum Jun)*** \\ 김 병 도(Kim, Byung-Do)****
}

기존 영화 산업에서 구전의 크기는 매출에 영향을 주지만 방향성은 영향을 주지 못하는 것으로 연구되었다(Liu 2006). 하지만, 이러한 분석 방법을 국내 영화 데이터에 동일하게 적용시켜 본 결 과, 구전의 방향성도 영화의 매출에 영향을 주는 것으로 밝혀졌다. 이는 아시아 지역의 소비자들에 게서 나타나는 독립적 자아관점과 북미 지역의 소비자들에게서 나타나는 상호의존적 자아관점의 차이로 인해 나타난 결과로 보인다. 즉, 국내 소비자의 경우는 영화를 선택/관람함에 있어 타인의 평가가 영향력을 주기 때문에 구전의 방향성도 유의한 양(+)의 값을 가진다.

기존의 연구에서는 구전의 크기가 일방적으로 매출에 영향을 미친다는 가정을 통해 영화 산업의 구전효과를 분석했으나, 이는 발생된 매출이 구전의 크기에 미치는 영향을 간과한 것이다. 따라서 매출이 구전에 미치는 효과까지 고려하여 연립방정식(Simultaneous Equation)을 통해 구전의 크기 와 매출 간 상호 관계를 추정한 결과, 구전의 방향성은 위의 분석과 동일하게 영화 개봉 후 지속 적으로 매출에 양(+)의 영향력을 미치는 것으로 나타났다. 하지만, 구전의 크기는 매출의 원인이 되는 것이 아니라, 오히려 매출이 증가하여 구전의 크기가 증가하는 것이라는 결과를 보여주었다. 즉, 개봉 후 1 주차에는 소비자들이 영화를 선택할 때 구전의 크기와 방향성이 동시에 고려되지만, 2 주차 이후로는 구전의 크기는 매출에 영향을 미치는 변수가 아니라, 매출의 증가에 따른 결과라 는 사실이 밝혀졌다.

핵심개념: 온라인 구전, 영화 매출, 영화 리뷰, 인터넷 포털, 연립방정식

\footnotetext{
* 본 연구는 서울대학교 경영대학 경영연구소에서 지원한 연구비로 수행되었음

** 서울대학교 경영대학 박사과정(95251101@naver.com)

*** 산업은행(bumdol1@hanmail.net)

**** 서울대학교 경영대학 교수(bxk@snu.ac.kr), 교신저자
} 


\section{I. 서 론}

소비자 간 정보 교환인 구전(Word of Mouth) 및 온라인 구전(eWOM: electronic Word of Mouth)은 기업 간 광고 경쟁의 심화로 인해 효 과가 떨어지고 있는 기존의 매스 미디어 상업 광고에 대한 대안으로 기업들의 관심과 마케팅 연구 대상이 되고 있다.

구전은 두 가지 주요한 점에서 기업의 광고 등 기존의 다른 정보 원천들과 구분된다. 첫째, 구전은 다른 정보 원천들보다 소비자들에게 더 믿을 수 있고 신뢰할 수 있는 정보 원천이다. $\operatorname{Beck}(1992)$ 은 구전이 자신과 유사한 상황에 처한 다른 소비자들로부터의 조언이기 때문에 소비자의 구매의사결정에 더 큰 힘을 발휘한다고 주장하며 다른 정보 원천과의 신뢰성 차이를 설 명하였다. 특히, 신제품의 선택에 있어서 소비자 들이 제품에 대해 인지하고는 있으나, 잘 알지 못하는 물품을 구매할 때 구전은 매우 중요하다 고 알려져 있다(Mahajan, Muller, and Kerin 1984). 영화와 같은 제품은 이러한 신제품이 가지는 특성을 가지고 있으며, 일반적으로 구전 이 사람들의 영화 선택에 큰 영향을 미친다고 연구되었다(Austin 1989; Bayus 1985; Faber and O'Guinn 1984; Neelamegham and Chintagunta 1999).

둘째, 광고가 매스미디어 채널을 통해 소비자 에게 전달되는 반면, 구전 정보는 사회 연결망 (Social network)을 통해서 소비자들이 쉽게 접근할 수 있다(Benerjee 1992; Brown and Reingen 1987; Murray 1991). 구전의 접근성 은 인터넷의 급속한 보급과 대중화로 인해 인
터넷 메신저, 게시판, 커뮤니티, 쇼핑 사이트의 구매 후기 등의 형태로 광범위하게 이루어지고 있으며, 온라인 구전은 과거 오프라인의 구전보 다 소비자의 정보탐색과 구매결정에 더욱 큰 영 향을 미치고 있다(Bussiere 2000; Chatterjee 2001). 많은 인터넷 사이트들의 구전자료들은 사용자들에게 제품에 대한 정보를 알려줄 뿐만 아니라 의견을 교환하는 데에도 이용되고 있으 며, 소비자들의 구매의사결정에 영향을 준다. 구전 데이터에 대한 해외 마케팅 연구로는 유 즈넷(Usenet) 뉴스그룹에서 TV 쇼를 대상으로 구전 정보의 효과를 연구(Godes and Mayzlin 2004)한 논문과 두 곳의 인터넷 서점(아마존과 반즈앤노블)의 리뷰 자료를 분석하여 매출액에 영향을 미치는 온라인 구전 정보의 효과를 연 구한 논문(Chevalier and Mayzlin 2006), 영화 매출액에 대한 영화 리뷰(Yahoo.com)의 영향을 연구한 논문(Liu 2006)이 있다. 국내의 구전에 대한 연구는 온라인 구전의 선행요인을 규명하 기 위한 연구(김성훈 2003; 김해룡, 최현국, 이 문규 2004; 이현선, 리대용 2004)가 주로 이루 어졌지만, 실제 온라인 데이터를 이용한 연구는 국내에서 찾아보기 어려웠다.

본 연구에서는 인터넷 포털의 영화 사이트에 남겨진 리뷰 평가의 크기(Volume)와 방향성 (Valence)이 영화 매출과 어떠한 상호 영향을 미치는지를 검증하려 한다. 2장에서 구전 효과 의 정의와 특성에 대한 관련 문헌을 통해 구전 이 인터넷 공간에서는 어떠한 특성을 가지는지 를 보이고, 영화 흥행에 영향을 미치는 변수들 과 온라인 구전이 결합되어 영화 매출에 미치 는 영향에 대한 연구들을 소개한다. 3 장에서는 
연구의 목적에 대한 설명을 하고, 4장에서는 연 구모델과 분석결과를 설명할 것이다. 마지막으 로 5장에서는 결론 및 시사점과 향후 연구 과 제를 제안하고자 한다.

\section{II. 이론적 배경}

국내 영화 산업에서 온라인 구전의 크기와 방향이 매출과 어떤 상호영향을 미치는지를 분 석하는 것이 본 연구의 목적이다. 따라서 일반 적인 구전의 정의 및 소비자가 구전에 의해 어 떠한 영향을 받는가에 대한 연구와 구전이 인 터넷 공간속에서 가지는 특성을 살펴본다. 또 한, 영화 흥행에 영향을 미치는 구전 이외의 변 수들을 제어하기 위해 관련 연구들을 참조하고, 구전과 매출과의 관계에 대한 연구들이 발전되 어온 결과를 볼 것이다.

\section{1 구전 커뮤니케이션의 정의와 특성}

구전(Word of Mouth)이라는 용어는 1954년 Fortune지에 소개된 Whyte의 마케팅 연구에서 처음 사용되었다(장세영, 2007; 황의록, 김창호, 1995). 구전에 대한 정의는 연구자들마다 조금 씩 차이가 있지만, 사람들의 입에서 입으로 전 해지는 정보라는 공통점을 찾을 수 있다. Zaltman and Wallendorf(1979)는 구전 커뮤니 케이션을 사람들이 자신의 상업적 이익과 무관 하게 대화를 통하여 직접적으로 정보를 전달, 획득하는 행위라 정의하였으며, Arker and
Myers(1982)는 구전을 광고의 측면에서 광고 수신자가 지인들에게 이야기를 함으로써 정보 원천이 되는 커뮤니케이션이라고 정의하였다. Ritchins(1983)는 구전을 소비자 시장에서 일어 나는 제품에 대한 정보의 교환과정으로 이해하 였다. 이상과 같은 정의를 종합하면 구전은 이 해관계를 떠나 자신의 직간접 경험을 비공식적 인 대화를 통해 정보를 전달, 획득하는 행위라 고 할 수 있다(황의록, 김창호 1995).

구전 커뮤니케이션은 정보 전달자가 기업의 이해관계와 관련 없이, 독립적인 자신의 판단에 따라 제품이나 서비스를 평가하므로 상업적인 광고보다 믿을 수 있는 정보의 원천이라 여겨지 고 있다(Silverman 2001). 실제 소비자는 구매 의사결정과정에 있어서 구전 정보의 영향을 많 이 받는데, 컨설팅 회사인 맥킨지의 통계에 따 르면 $67 \%$ 의 소비자가 구전에 의지하여 소비재 를 구매한다고 한다(Taylor 2003). 특히, 신제 품 선택의 경우는 정보 부족으로 인한 위험이 존재하기 때문에 구전이 더 중요한 역할을 하 는 것으로 알려져 있다(Mahajan, Muller, and Kerin 1984). 이는 구전이 믿을 수 있는 정보 를 제공하여 소비자의 의사결정에 수반되는 위 험을 낮추어주는 역할을 하기 때문이며, 구전의 효과는 발신자의 전문성(Arndt 1967), 제품에 대한 소비자 관여도와 지식(양윤, 조문주 2000) 등에 따라 영향을 받는다. Trusov et al.(2009) 은 신규고객을 획득하는데 있어서 전통적인 마 케팅 기법과 구전 효과를 비교하고, 구전 효과가 기존의 마케팅 기법에 비해 장단기 적으로 지속 성이나 강도 측면에서 더 효과적임을 밝혔다. 


\section{2 온라인 구전의 정의와 특성}

온라인 구전은 인터넷이라는 가상공간에 존 재하는 구전(이태민, 박철 2006; 김해룡 외 2004; 이은영 2004; Bussiere 2000; HenningThurau and Walsh 2003; Henning-Thurau et al. 2004)이라 할 수 있으며, 인터넷의 동호 회 커뮤니티, 인터넷 쇼핑몰의 리뷰, 쇼핑 후기, 평가 점수 등은 이러한 온라인 구전의 예라 할 수 있다. 이러한 온라인 구전의 특성은 다음과 같다(이태민, 박철 2006).

Chatterjee(2001)는 오프라인에서 이루어졌 던 기존의 구전에 비해 대규모로 동시에 다양 한 정보원으로부터 긍정적인 정보와 부정적인 정보를 동시에 접하게 된다고 하였으며, 온라인 구전 정보의 형태는 비교적 매우 다양하므로, 각각 그 접근성, 범위, 정보원천이 매우 다양하 다고 하였다(이태민, 박철 2006). 이은영(2004) 과 Dellarocas(2003)는 오프라인 구전과 달리 온라인 구전의 저장가능성과 다수의 동시 접근 성을 지적하였고, Chevalier and Mayzlin (2006)과 Henning-Thurau et al.(2004)은 온 라인 구전이 인터넷의 특성으로 익명성을 가지 며, 시공간의 제약을 받지 않는 자유롭고 편리 한 커뮤니케이션이라고 하였다.

온라인 구전은 어떠한 수단을 사용하느냐에 따라서도 다양한 결과를 낳을 수 있는데, 기업 이 익명성을 가장하여 소비자의 의견으로 가장 하여 마케팅 기법의 하나로 사용할 수도 있으 며 전통적 기법의 마케팅보다 효율이 좋을 수 있다(Mayzlin 2006). Chen and Xie(2008)는 판매자가 제시하는 상품설명과 소비자의 온라
인 상품평가의 관계를 검증하였다. 상품 비용이 낮거나 상품지식이 풍부한 소비자들이 많을수 록 판매자의 제품 기능위주의 설명과 소비자의 온라인 상품평가는 보완적인 역할을 한다고 하 였다.

온라인 구전은 대규모의 정보를 신속하게 전 파할 수 있는 통로이고(Bickart and Schindler 2002; Chatterjee 2001), 전통적인 마케팅 기 법과 더불어 다양한 온라인 구전을 통해 고객 에게 접근하는 방법이 연구되고 있다.

\section{3 영화의 흥행요인에 대한 연구}

영화의 흥행 요인에 대한 연구는 크게 영화 제품의 속성과 정보원에 대한 연구로 구분된다 (이소민 2005). 우선 영화 제품의 속성에 대한 연구는 Linton and Petrovich(1988)가 인물, 스토리, 영화배경 등 영화의 15 가지 속성들에 대한 연구를 수행하여 인물, 스토리, 연기속성 들이 중요한 흥행의 요인이 됨을 밝혔다. 이후 Litman and Kohl(1983)은 영화의 흥행 요인을 영화의 내재적 속성 차원에서 연구하여 창의영 역인 제품 속성(장르, 스타배우, 영화 등급, 제 작국가, 제작비용)과 스케줄 및 배급 마케팅 노 력으로 구분하였다.

정보원의 영향력에 관한 연구는 비평, 예고 원, 광고, 구전에 대한 연구가 주로 이루어졌다 (이소민 2005). 연구 논문에 따라 각각의 항목 에 대해 유의한 영향력을 가진 요인에 차이점 이 있었지만, 구전과 비평이 정보원 중 가장 큰 부분을 차지하고 있음을 확인할 수 있다.

영화 흥행에 있어 구전의 중요성은 많은 논

\section{4 한국마케팅저널 제12권 제2호 2010년 7월}


문들을 통해 증명되었다. Faber and O'Guinn (1984)은 영화 평가에 있어서 예고편(Preview) 과 구전이 다른 정보원보다 신뢰할만하다고 주 장하였으며, 구전이 소비자의 기대, 평가, 선택 혹은 흥행에 중요한 영화를 미친다는 결론을 가진 논문들이 다수이다(성영신, 박진영, 박은아 2002; 신선미 2001; Austin and Fordon 1987; Mahajan et al. 1984; Levene 1992; Zufryden 1996).

영화 비평에 관련된 연구는 구전에 관한 연 구와 달리 다양한 주장이 혼재하고 있다. Hirschman and Pieros(1985)는 영화 매출과 비평과의 관계에 음(-)의 관계가 존재하는 것을 밝혔으며, Faber and O'Guinn(1984)은 비평보 다 다른 중요한 영화의 요소가 있음을, Eliashberg and Shugan(1997)은 시간에 따라 영화 비평의 영향력이 달라지는 것을 확인하였 다. Litman(1983)은 배급사, 크리스마스 개봉, 비평을 흥행의 주요 원인으로 꼽았으며, Basuroy et al.(2003)은 비평이 영화 초기와 후기에 영화 의 흥행을 예측하는 예견자(Predictor)라 하였 다. 이상과 같이 영화의 비평에 대한 연구는 다 양한 주장이 혼재하고 있으며, 매출에 대한 영향력 측면에서는 통일된 견해가 존재하지 않는다.

\section{4 영화의 구전효과에 대한 선행 연구}

영화 산업은 고위험/고수익의 특성을 가지고 있는 산업이며, 10 개의 영화가 만들어지면 6 개 에서 7 개에 달하는 영화가 수익성이 없다는 연 구결과가 있다(Liu 2006; Vogel 2001; Shugan
1995). 대형 영화 제작사나 배급사에서도 소수 의 블록버스터 영화가 수익의 대부분을 차지하 기 때문에, 이에 대한 광고비용을 증가시키고 있다(Eliashberg et al. 2006). 영화 산업의 특 성으로 흥행에 영향을 미치는 다양한 요인들이 연구되었으며, 구전 효과는 주요 원인 중 하나 로 인식되고 있다.

구전의 중요한 속성으로는 크기(Volume)와 방향성(Valence)이 연구되었다(Mahajan et al. 1984; Mizerski 1982; Neelamegham and Chintagunta 1999). 구전의 크기(Volume)는 구전 메시지의 양을 말하며, 구전의 방향성 (Valence)은 구전 메시지의 긍정적, 부정적인 정도를 가리킨다.

Dellarocas et al.(2004)는 Bass 모델을 기 초로 개봉 주의 사용자 평가 점수를 이용해 Bass parameter(p, q)인 혁신지수(p)와 모방지 수 $(\mathrm{q})$ 를 추정하였다. 첫 주의 사용자 평가 점수 의 크기와 밀도(개봉 첫 주의 영화 매출액과 사 용자 평가 점수의 크기의 비율)가 $\mathrm{p}$ 를 추정하는 데 유용하며, 평가 점수는 $\mathrm{q}$ 에 대해 설명력이 있음을 알아내었다. Duan et al.(2005)은 개봉 후 2 주간 영화 평점과 매출액간의 일일 관계를 패널 데이터 분석을 통해 연구하였고, 사용자 평가 점수는 영화 매출에 유효한 설명력을 가 지지 못하지만, 구전의 크기(Volume)는 매출액 에 대해 설명력을 가진다고 결론을 내렸다. $\mathrm{Liu}(2006)$ 는 영화 개봉 전의 구전 효과의 방향 성(Valence)이 개봉 후에 높은 기대로 인해 낮 아짐을 발견하였고, 구전의 크기(Volume)가 영 화 매출액에 영향을 미치는 것을 확인하였다. 그의 연구에 따르면, 구전의 방향성(Valence)은 
매출액에 유효한 설명력을 가지지 못하였다. Moon et al.(2010)은 영화의 매출이 일반 관객 들의 평가인 구전의 방향성에 양(+)의 영향을 주고, 구전효과(전문가의 평점 및 일반 관객의 평점)는 광고와 동시에 사용될 경우만 매출에 유의한 영향을 미친다고 주장하였다.

영화 산업에서 구전에 대한 연구는 크기와 방향성을 중심으로 연구 되었으며, 본 연구에서 는 구전의 크기, 방향성, 매출 간 상호관계를 분석할 것이다.

\section{III. 연구목적}

영화 산업과 구전과의 관계를 다룬 기존 연 구들에서 구전의 크기는 매출액에 양(+)의 영 향을 주지만, 구전의 방향성은 매출에 영향을 주지 못하는 것으로 밝혀졌다(Liu 2006; Duan et al. 2005). 하지만, 기존 연구들은 주로 미국 의 데이터를 사용하여 분석하였기 때문에, 국내 데이터의 경우도 동일한 구전효과를 보이는지
재검증 할 필요가 있다. Liu(2006)는 온라인 구 전이 영화에 미치는 영향을 검증하기 위해 야 후 무비 사이트 (movie.yahoo.com)의 영화 40 편 및 해당 영화에 대한 온라인 댓글 12,136 개 를 분석하였다. 본 연구에서는 네이버 영화 사 이트의 439편의 영화, 746,282 개의 온라인 댓 글을 사용한 국내 데이터로 확장하고 위와 동 일한 모델을 사용하여 구전의 크기와 방향성에 대한 재검증을 할 것이다. 표본 수 증가를 통해 통계분석의 신뢰성을 높일 수 있고, 국내 데이 터 사용을 통해 구전효과의 국가 간 차이가 존 재하는지를 살펴볼 수 있을 것이다.

또한, 구전의 크기와 매출 간 관계에 대한 새 로운 구조를 제시하고, 기존 모델에서 간과한 부분에 대한 보완을 통해 새로운 결론을 도출 할 것이다. 영화산업에 관한 연구들에서 구전은 일방적으로 매출에 영향을 주는 독립 변수로 가정되어 왔다. 하지만, 구전을 통해서 발생된 매출은 다시 구전의 크기에 영향을 주고, 동시 에 증가된 구전의 크기는 매출에 영향을 준다 고 가정하는 것이 더 현실적이다. 즉, 기존연구

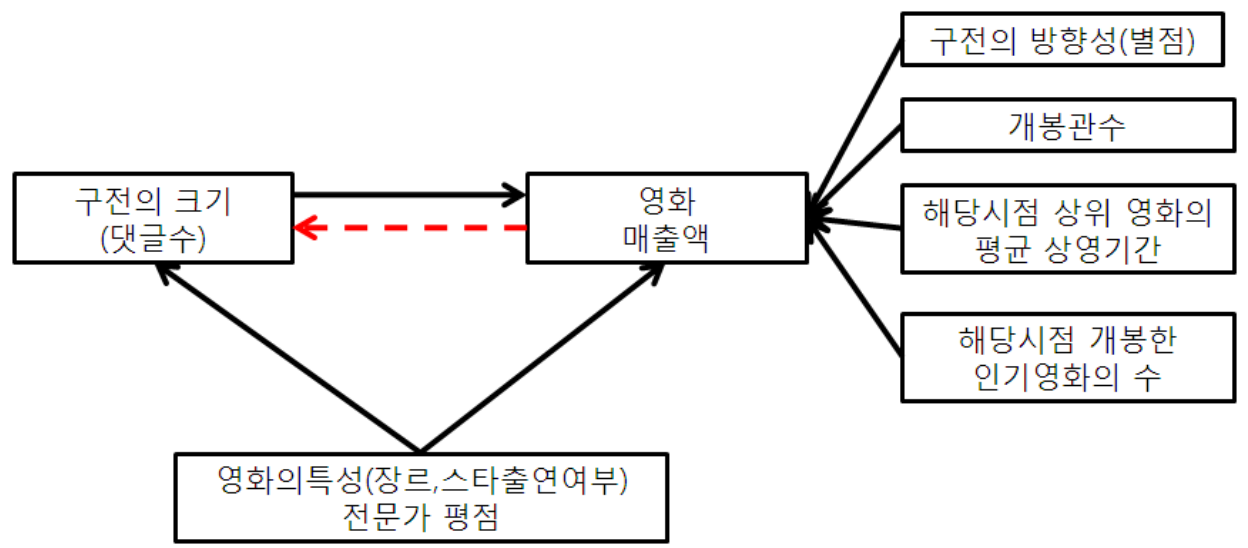

〈그림 1〉영화 매출과 구전의 관계 
에서는 〈그림 1>의 점선부분 효과는 분석대상 에서 제외되었고, 구전과 매출에 상호 영향을 주는 내생적 관계에 있다는 점을 배제하였다. 따라서 매출과 구전의 크기가 상호 동시적으로 영향을 준다는 사실을 가정하고, 두 변수를 내 생 변수로 정의하여 연립방정식 (Simultaneous Equation)을 통해 재분석 할 것이다. 이를 통 해, 구전의 크기가 일방적으로 매출에 영향을 주는 것인지, 매출이 구전에 영향을 주는 것인 지, 또는 두 변수가 서로의 원인이 되는 것인지 에 대한 명확한 결론을 내릴 수 있을 것이다.

마지막으로, 전문가들의 평점 혹은 전체 평론 중 호의적 평가의 비중은 어느 정도의 논란이 있긴 했지만, 영화 매출에 양(+)의 영향을 미치 는 변수라는 연구들이 다수 존재했다(Litman 1983; Eliashberg and Shugan 1997). 이러한 전문가 평점이 국내에서도 동일하게 양 $(+)$ 의 영 향력을 가지는지에 대한 부분을 분석할 것이다.

\section{IV. 연구모델}

\section{1 자료의 수집}

데이터의 수집은 네이버 영화, 영화입장권 통 합전산망, 인터파크 영화 웹 사이트를 대상으로 하였으며, 수집 로봇(Robot)을 직접 프로그래밍 하여 데이터를 수집하였다. 영화 구전 데이터를 가지고 있는 수많은 웹 사이트 중에서 네이버 영화를 택한 이유는 다음과 같다. 첫째, 타사에 비해 월등히 많은 회원 수 3200만 명(2008년 8월 기준)을 보유하고 있어, 영화 구전에 관련
된 다양한 표본을 모두 수집할 수 있으며, 모든 국내 개봉 영화에 대해 평가가 가능한 시스템 을 갖추고 있다. 둘째, 소비자는 영화에 대해 평가를 하기 위해 로그인을 하여야 하며, 동일 영화에 대해 1 번만 평가가 가능하기 때문에 소 수의 평가자에 의한 여론 조작이 방지되어 있 다. 셋째, 각 영화별 구전 작성의 날짜, 시간, 별점이 개인ID와 함께 저장이 되며 작성자 본 인이 해당 정보를 삭제하지 않는 한 영화 정보 및 댓글 정보는 영구적으로 보존된다. 해당 영 화에 작성된 댓글 숫자를 날짜별로 측정하여 주간 단위로 합산하여 구전의 크기 변수로 설 정하고, 댓글에서 평가된 별점의 주간 단위 평 균을 구전의 방향성 변수로 설정하여 개봉 후 해당 시점의 구전의 방향성과 크기를 정확히 측정할 수 있다. 마지막으로, 영화 관람자들의 평가뿐만 아니라 평가 후의 관람 평을 리뷰형 식으로 공유할 수 있도록 하였으며, 영화 사이 트 내에 씨네 21 , 필름 2.0 과 같은 영화 전문 잡지의 평가, 관련 기사 등을 소비자들이 보기 쉽게 제공하고 있기 때문에 추가 데이터의 수 집도 가능하다.

영화의 매출 데이터는 영화입장권 통합전산 망에서 2005년 1월부터 2007년 12월까지 일 일 단위로 제공하는 기간별 박스 오피스 페이 지의 정보를 수집하였으며, 이를 영화 개봉일을 기준으로 주간 단위 합산하였다.

상영 등급, 상영시간, 영화의 장르 등과 같은 영화 정보는 네이버 영화 사이트에 누락되어 있는 경우가 많기 때문에 해당 정보가 충실한 인터파크의 정보를 수집하여 사용하고 두 자료 를 비교하였다. 상영등급은 네이버 정보와 비교 
하였을 때 누락된 부분을 제외하면 일치하였으 며, 상영시간 역시 누락정보를 제외하면 일치하 였을 뿐 아니라, 분석에서 제외된 변수이기 때 문에 문제가 없는 것으로 판단된다. 영화장르의 경우는 복합 장르로 인해 일부 차이가 존재하 였으나 장르 부분을 제외하고 분석하였을 때, 다른 변수들의 통계적 유의성에 영향을 미치지 않는 다는 것을 검증하였다.

\section{2 변수의 정의 및 기초통계 분석}

영화의 매출액 데이터(LNREV)는 영화입장권 통합전산망에서 일간 단위로 수집한 자료를 프 로그램을 이용하여 주간 단위로 합산(1-8주)하 여 주 단위 데이터를 사용하였다.

구전 데이터는 네이버 영화 사이트에서 작성 자 $\mathrm{ID}$ 별 댓글, 평점, 작성 일자 정보를 수집하 였다. 구전의 크기 변수(LNMSG)는 해당영화에 대한 댓글의 수를 개봉일 기준으로 8주간 날짜 별로 수집한 뒤 주간단위로 합산하여 설정하였 다. 구전의 방향성 변수(RATING)도 개봉일 기 준으로 개인들이 평가한 별점의 평균을 주간단 위로 측정하여 설정하였다.

영화 개봉관 수(SCRN)는 영화 매출액에 주 요한 영향을 주는 변수이며 각 상영관의 일정 에 따라 일간으로 스크린 수가 변동한다. 따라 서 영화입장권 통합전산망에서 일간 단위로 수 집한 자료를 프로그램을 이용하여 주간 단위로 합산(1-8주)하여 평균을 내어 사용하였다.

영화 개봉 정보는 영화입장권 통합전산망의 영화 이름을 기준으로 네이버 영화, 인터파크 영화의 영화 이름과 정보를 매칭하였으며, 관람
등급(DPG, DR), 장르(GACTION, GCOMEDY, $\mathrm{GSF})$, 스타 출연 정보(STAR) 등 세부 정보는 1 차적으로 인터파크 영화의 정보를 이용하였고, 인터파크 영화 내에 영화 정보가 존재하지 않 을 경우 네이버 영화의 정보를 이용하였다. 해 당 자료들은 구전의 크기 및 매출에 영향을 미 치는 변수로 관람 등급이 높을수록 관객 수가 적어 구전의 크기에 음(-)의 영향을 미칠 것이 고, 스타의 영화 출연은 구전의 크기와 매출에 양 $(+)$ 의 효과를 줄 수 있다. 영화 장르의 경우 장르별 구전의 크기에 차이가 있는지 검증하기 위해 변수화 하였다.

전문가 점수(CRATING)는 네이버 영화 내의 씨네 21 평가 점수를 이용하였다. 씨네 21 의 평 가 점수는 여러 명의 전문가의 평가 점수를 평 균한 것으로써, 10점 만점으로 점수가 높을수 록 평가가 긍정적임을 나타낸다. 전문가 점수는 선행연구에서 밝혔듯이 구전 및 매출에의 영향 력이 논란의 여지가 있기 때문에, 국내 데이터 의 경우 전문가 점수가 통계적 유의성을 가지 는 양(+) 또는 음(-)의 방향성을 가지는지 검증 하기 위해 변수화 하였다.

$\mathrm{t}$ 주에 개봉한 영화중 10 위 이내에 오른 영화 수(NEW)는 $\mathrm{t}$ 주 주간 영화 10 위 중 $\mathrm{t}$ 주차에 개 봉한 영화의 수를 의미한다. Top10 영화 상영 기간(AGE)은 t주 영화 순위 중 10 위 안에 해당 하는 영화의 평균 상영 기간을 의미한다. 두 변 수(Elberse and Eliashberg 2003)는 해당 주 간의 경쟁의 정도를 나타내는 변수로, 전자의 경우 $\mathrm{t}$ 주에 새로 개봉한 영화 중 10 위권 안에 든 인기 영화의 수가 많다면 분석 대상이 되는 영화의 구전 등록 수는 상대적으로 줄어들 것 
이다. 후자의 경우 10 위권 안의 인기영화의 평 균 상영기간이 짧을수록 이 영화들의 구전의 양이 많아지기 때문에, 분석 대상이 되는 영화 에 대한 구전의 양이 줄어들 수 있다. 이 자료 들은 영화입장권 통합전산망의 주간 순위 데이 터를 수집하여 추출하였다. 통계분석에 사용된 변수들의 이름과 의미는 <표 1 과 같이 정리할 수 있다.

수집한 정보들 중 분석 대상은 2005년 1월 1 일부터 2007년 12월 31일까지 개봉한 영화로 한정하였으며, 예술 영화 및 독립 영화, 재개봉 영화들의 경우 관객의 수가 작거나, 혹은 구전 의 효과를 판단하는데 적절치 않은 자료라고 판단되어 개봉 후 8 주내 관객이 10 만 명이 되 지 않는 영화를 제외하여 총 439편의 영화를
대상으로 하였다. 관객 수가 작을 경우 평균 별 점을 사용하는 본 연구에서 소수의 고객들이 평가한 점수가 영화를 대표하는 점수가 될 수 있기 때문에 배제하는 것이 적절하다 판단하였 다. 총 관람객 수는 4억 508만명, 총 구전의 수 는 746,282 개, 총 매출은 2 조 5,023 억, 전문가 평점의 수는 1,105 개이다. 이 외 통계분석에 사 용된 변수들 및 영화 산업에서 중요시 되는 변 수들의 기초 통계값은 <표 2>와 같다.

\section{3 실증분석 결과}

첫째, 미국 야후 영화 사이트의 정보를 사용 한 기존 구전효과와 매출과의 관계 모델(Liu, 2006)이 국내 네이버 영화 사이트의 데이터를

〈표 1〉구전과 매출과의 관계분석에 사용된 변수 항목

\begin{tabular}{|c|l|}
\hline 변수명 & \\
\hline$t$ & 영화 개봉 후 시간경과(주간 단위) \\
\hline$A G E_{t}$ & t주 상위 10 개 영화의 평균 상영기간 \\
\hline$C R A T I N G$ & 전문가평점 \\
\hline$D P G$ & 전체 관람가 \\
\hline$D R$ & 18 세 이상 관람가 \\
\hline$G A C T I O N$ & 영화장르가 액션/모험물 \\
\hline$G C O M E D Y$ & 영화장르가 코미디 \\
\hline$G S F$ & 영화장르가 $\mathrm{SF}$ \\
\hline$L N M S G_{t}$ & $\mathrm{t}$ 주의 구전 수 (자연로그) \\
\hline$L N R E V_{t}$ & $\mathrm{t}$ 주의 영화 매출액 (자연로그) \\
\hline$N E W_{t}$ & $\mathrm{t}$ 주에 개봉한 영화 중 상위 10 위 이내 영화 수 \\
\hline$R A T I N G_{t}$ & t주의 관람객 평점 평균 \\
\hline$S C R N_{t}$ & t주의 상영관수 \\
\hline$S T A R$ & 스타배우의 영화출연여부 \\
\hline
\end{tabular}

* 개별 영화를 나타내는 subscript $i$ 는 생략하였음 
〈표 2〉영화 표본에 대한 기초통계량 분석

\begin{tabular}{|l|c|c|c|}
\hline \multicolumn{1}{|c|}{ 변수명 } & 평균 & 중앙값 & 표준편차 \\
\hline 총 관람객 수 & 922,738 & 456,859 & $1,284,716$ \\
\hline 누적 매출(백만) & 5,700 & 2,783 & 7,971 \\
\hline 개봉 첫주 개봉관 수 & 147.1 & 129.5 & 83.9 \\
\hline 개봉 첫주 구전의 수 & 441.9 & 209.0 & $1,121.4$ \\
\hline 개봉 첫주 평점 & 7.23 & 7.43 & 1.42 \\
\hline 누적 구전 수 & $1,705.3$ & 827.0 & $3,412.4$ \\
\hline 누적 평점 & 6.99 & 7.23 & 1.47 \\
\hline 전문가 평점 & 5.51 & 5.5 & 1.14 \\
\hline
\end{tabular}

사용하였을 때 계수 값의 방향성과 유의성 차 이가 있는지를 검증하기 위해 동일한 모델에 국내데이터를 사용하여 회귀분석을 실시하였다. 둘째, 첫 번째 모델에서 고려하지 못한 구전의 크기와 매출간의 상호관계를 가정하고 연립방 정식(Simultaneous Equation)을 사용하여 각 변수들의 계수 값을 추정하였다. 이 결과를 첫 번째 모델과 비교하여 각 독립변수들의 계수 값의 방향성이나 통계적 유의성이 변화하였는 지를 살펴보고, 변화한 부분에 대한 원인이 무 엇인지를 분석하였다. 영화 개봉 후 시간의 흐 름에 따라 각 독립변수들이 종속변수에 미치는 영향이 차이가 있는지를 확인하기 위해 개봉 후 1주 단위로 세분화 하여 1 8주차까지 회귀 분석 및 연립방정식 분석을 하였다.

\subsection{1 구전의 크기와 방향성}

영화산업에서 구전의 크기는 영화매출에 양 (+)의 영향을 미치지만, 방향성은 영향을 주지 못하는 것으로 밝혀졌지만(Liu,2006), 국내 데
이터를 해당 모델에 적용시켜 <식 1 >과 같이 동일한 회귀분석을 한 결과, 구전의 크기뿐만 아니라 방향성 또한 매출에 유의한 영향을 준 다는 사실을 발견하였다.

$$
\begin{aligned}
& L N R E V_{i, t}=\beta_{0}+\beta_{1} L_{N M S G_{i, t}}+\beta_{2} \text { RATING }_{i, t} \\
& \quad+\beta_{3} S C R N_{i, t}+\beta_{4} C R A T I N G_{i}+\beta_{5} N E W_{t} \\
& \quad+\beta_{6} A G E_{t}+\epsilon_{i, t}
\end{aligned}
$$

<식 1 >에서 $i$ 는 개별 영화를 나타내고 $(i$ $=1,2,3, \cdots, 439), t$ 는 개봉 후 경과한 시간(주간 단위)를 의미하며 $(t=1,2,3, \cdots, 8)$, 잔차항은 $\epsilon_{i, t} \sim N\left(0, \sigma_{i}^{2}\right)$ 의 분포를 따른다고 가정한다. <표 $3>$ 에서 각 변수의 상단 값은 계수값을 의미하 고, 하단 값은 $\mathrm{p}$-value를 의미한다. 구전의 크 기(LNMSG)는 개봉 후 1 8주 기간 모두 영화 매출에 유의한 양(+)의 영향을 미치는 것을 알 수 있다 $(\mathrm{p}<0.05)$. 또한, 구전의 방향성 (RATING) 역시 개봉 후 1 주차와 8주차를 $(\mathrm{p}<0.1)$ 제외한 전 기간에 걸쳐 유의수준 0.05 
하에서 유의한 양(+)의 값을 보여주고 있다. 전 자의 경우 기존과 동일한 결과를 보여주지만, 후자의 경우 기존의 연구들(Liu 2006; Duan et al. 2005)에서 구전의 방향성이 매출에 대한 영 향력이 없다고 보여줬던 결과와 차이가 있다. 이는 데이터의 원천이 어디냐에 따라 다른 결 과가 나온 것이기 때문에, 구전의 방향성에 국 가 간 차이가 존재한다는 사실을 의미한다.

Markus and Kitayama(1991)의 논문에 따 르면 자아의 많은 측면은 문화, 사회적 영향을 받아 보편적이지 않으며, 자아 스스로 다른 사 람들과 분리시키거나 관련시키려는 정도에 따 라 독립적 자아관점(Independent self construal)
과 상호의존적 자아관점(Interdependent self construal)으로 나뉜다고 하였다. 일반적으로 독립적 자아관점은 북미와 유럽 문화에 광범위 하게 퍼져있고, 상호의존적 자아관점은 아시아 와 아프리카, 남미 등의 국가에 존재하는데, 자 아 관점의 차이가 사람들의 인지, 감정, 동기에 유의적인 영향을 미친다고 밝혔다. 동서양 자아 관점의 차이가 존재한다는 사실에 근거하여 본 연구결과와 기존의 연구결과의 차이점을 설명 할 수 있다. 서양의 독립적 자아관점을 가진 관 람객들의 경우 영화에 관한 타인의 평가에 대 한 인지, 감정의 영향이 상호의존적 자아관점을 가진 동양인에 비해 작다고 할 수 있으며, 평가

〈표 3〉 구전의 크기와 방향성이 매출에 미치는 효과

\begin{tabular}{|c|c|c|c|c|c|c|c|c|}
\hline \multicolumn{9}{|c|}{$\begin{aligned} \operatorname{LNREV}_{i, t}= & \beta_{0}+\beta_{1} \operatorname{LNMSG}_{i, t}+\beta_{2} \operatorname{RATING}_{i, t}+\beta_{3} S C R N_{i, t}+\beta_{4} C R A T I N G_{i}+\beta_{5} N E W_{t} \\
& +\beta_{6} A G E_{t}+\epsilon_{t}\end{aligned}$} \\
\hline & 1주 & 2주 & 3주 & 4주 & 5주 & 6주 & 7주 & 8주 \\
\hline \multirow{2}{*}{$\begin{array}{l}\text { CONST } \\
\text { 상수항 }\end{array}$} & 17.96 & 18.65 & 17.34 & 14.49 & 13.17 & 12.16 & 11.38 & 11.45 \\
\hline & $0.00 * *$ & $0.00 * *$ & $0.00 * *$ & $0.00 * *$ & $0.00 * *$ & $0.00 * *$ & $0.00 * *$ & $0.00 * *$ \\
\hline \multirow{2}{*}{$\begin{array}{l}\text { LNMSG } \\
\text { 구전크기 }\end{array}$} & 0.37 & 0.30 & 0.36 & 0.43 & 0.42 & 0.42 & 0.63 & 0.59 \\
\hline & $0.00 * *$ & $0.00 * *$ & $0.00 * *$ & $0.00 * *$ & $0.00 * *$ & $0.00 * *$ & $0.00 * *$ & $0.00 * *$ \\
\hline \multirow{2}{*}{$\begin{array}{l}\text { RATING } \\
\text { 구전방향 }\end{array}$} & 0.03 & 0.05 & 0.11 & 0.20 & 0.22 & 0.28 & 0.17 & 0.18 \\
\hline & 0.05* & $0.00 * *$ & $0.00 * *$ & $0.00 * *$ & $0.00 * *$ & $0.00 * *$ & $0.02 * *$ & $0.06 *$ \\
\hline \multirow{2}{*}{$\begin{array}{l}\mathrm{SCRN} \\
\text { 개봉관수 }\end{array}$} & 0.00 & 0.01 & 0.01 & 0.02 & 0.02 & 0.03 & 0.03 & 0.04 \\
\hline & $0.00 * *$ & $0.00 * *$ & $0.00 * *$ & $0.00 * *$ & $0.00 * *$ & $0.00 * *$ & $0.00 * *$ & $0.00 * *$ \\
\hline \multirow{2}{*}{$\begin{array}{l}\text { CRATING } \\
\text { 전문가평점 }\end{array}$} & -0.06 & -0.07 & -0.09 & -0.13 & -0.09 & -0.05 & -0.02 & -0.06 \\
\hline & $0.00 * *$ & $0.00 * *$ & $0.00 * *$ & $0.00 * *$ & $0.01 * *$ & 0.18 & 0.73 & 0.23 \\
\hline \multirow{2}{*}{$\begin{array}{c}\text { NEW } \\
10 \text { 위권내 } \\
\mathrm{t} \text { 주 개봉작수 }\end{array}$} & -0.03 & -0.11 & -0.11 & 0.00 & -0.03 & 0.01 & 0.00 & -0.09 \\
\hline & 0.22 & $0.00 * *$ & $0.00 * *$ & 0.98 & 0.76 & 0.91 & 0.98 & 0.62 \\
\hline \multirow{2}{*}{$\begin{array}{c}\text { AGE } \\
10 \text { 위권내 영화 } \\
\text { 평균상영기간 }\end{array}$} & 0.06 & -0.11 & -0.15 & -0.02 & 0.17 & 0.07 & 0.19 & 0.36 \\
\hline & 0.22 & $0.02 * *$ & $0.01 * *$ & 0.86 & 0.27 & 0.67 & 0.42 & 0.18 \\
\hline
\end{tabular}

* : $\mathrm{p}<0.1 * *: \mathrm{p}<0.05$ 
점수의 영화 매출에 대한 영향력이 작게 나타 나는 근거가 된다. 즉, 타인의 평가에 영향을 덜 받으며, 개인의 판단에 따라 영화를 선택/관 람하는 경향이 더 강한 것이다. 반면 상호의존 적 자아관점을 가진 동양인들의 경우 영화에 대한 타인의 평가가 인지, 감정에 미치는 영향 이 크게 나타나며, 영화 선택 및 관람에 큰 영 향을 받는다고 할 수 있다. 이는 동양권에 속하 는 우리나라의 경우에도 동일하게 적용됨을 분 석 결과에서 알 수 있다. 영화를 보러 가기 전 자신이 관람할 영화에 대한 타인의 평가를 미 리 확인하고, 평가 점수가 낮을 경우 선택한 영 화를 포기하거나 평가 점수가 높은 다른 영화 를 보기 때문에, 구전의 방향성이 매출에 유의 한 영향을 준다.

기존 연구들(Litman 1983; Eliashberg and Shugan 1997)과 또 다른 결과를 보여주는 변 수는 전문가 평점이다. 전문가 평점이 영화매출 에 미치는 영향은 개봉 1 5주차까지 통계적으 로 유의한 음(-)의 값을 가지고 있다. 이는 국 내 영화 관람객들의 경우 영화 관람 시 높은 전문가 평점을 받은 영화의 관람을 기피하고, 낮은 평점의 영화를 오히려 선호하는 것을 의 미한다. 영화 전문 웹사이트인 '맥스무비'에서 2009년 1월 6일부터 9일까지 3일에 걸쳐, 영 화 관람 시 누구의 평이 가장 많은 영향을 미 치는지에 대한 설문조사를 했고, 3,255 명의 응 답을 받았다. 1 위가 $86.35 \%$ 로 관객의 평, 2 위 가 네티즌 평 $8.27 \%, 3$ 위가 평론가 평 $4.03 \%$ 로 나타났다. 이러한 결과의 원인은 다양하겠지 만, 국내 관객들에게 전문가들의 평가는 흥행성 과 상반된다고 인식되는 경향이 있다. 즉, 흥행
성이 높은 영화에는 낮은 평점을, 예술성이 높 은 영화에는 높은 평점을 주는 것으로 알려져 있는 점이 관객들이 전문가 평점을 신뢰하지 않는 가장 큰 원인으로 보인다. 또한, 평론가들 은 일반적인 관객들 보다 영화를 접하는 횟수 가 월등히 많기 때문에 평가 점수가 일반 관객 들이 내리는 평가 점수와 차이가 생기게 되고, 일반 관객들은 자신과 동일한 수준에 있는 사 람들의 평가 점수를 더 신뢰하게 되는 것이다.

\subsection{2 구전의 크기와 매출 간 상호관계}

첫 번째 통계분석의 결과 국내 영화 데이터 의 경우 구전의 크기와 방향성이 모두 영화 매 출에 영향을 미치는 것으로 나타났다. 그러나 구전과 매출간의 관계는 구전이 매출에 영향을 주는 일방적인 관계라고 볼 수 없다. 즉, 구전 의 크기가 커짐과 동시에 매출이 오르고, 매출 은 다시 구전에 영향을 주는 구조라고 보는 것 이 더 현실성이 있다. 따라서 구전의 크기가 매 출에 영향을 주는 <식 1 >과 매출이 구전에 영 향을 주는 모델인 <식 2>를 연립방정식 (Simultaneous Equation)으로 구성하고 모델을 설정하였다. 이를 통해 구전의 크기와 매출 중 어떠한 변수가 원인이 되는지, 혹은 상호 원인 이 되는지를 밝힐 수 있을 것이다.

$$
\begin{aligned}
& L N R E V_{i, t}=\alpha_{0}+\alpha_{1} L_{N M S G_{i, t}}+\alpha_{2} \text { RATING }_{i, t} \\
& \quad+\alpha_{3} S C R N_{i, t}+\alpha_{4} C R A T I N G+\alpha_{5} N E W_{t} \\
& \quad+\alpha_{6} A G E_{t}+\epsilon_{i, t}
\end{aligned}
$$




$$
\begin{aligned}
& \text { LNMSG }_{i, t}=\beta_{0}+\beta_{1} \text { LNREV }_{i, t}+\beta_{2} \text { STAR }_{i} \\
& \quad+\beta_{3} \text { GCOMEDY }_{i}+\beta_{4} \text { GACTION }_{i}+\beta_{5} G S F_{i} \\
& +\beta_{6} \text { CRATING }_{i}+\beta_{7} D P G_{i}+\beta_{8} D R_{i}+\epsilon_{i, t}
\end{aligned}
$$

<식 1>과 <식 2>에서 $i$ 는 개별 영화를 나타 내고 $(i=1,2,3, \cdots, 439), t$ 는 개봉 후 경과한 시간 (주간 단위)를 의미하며 $(t=1,2,3, \cdots, 8)$, 잔차항 은 $\epsilon_{i, t} \sim N\left(0, \sigma_{i}^{2}\right)$ 의 분포를 따른다고 가정한다. <식 1 >의 경우 1 번 결과의 식을 동일하게 사용 하였고, <식 2>의 경우는 구전의 크기가 (LNMSG)종속 변수가 되고, 구전의 크기에 영 향을 미치는 스타출연여부 더미 변수(STAR),
장르 더미 변수(GCOMEDY, GACTION, GSF), 관람등급 더미 변수(DPG, DR)를 기존 연구들 을 참조하여 추가하였다. <식 1>과 <식 2>에 서 내생변수는 매출액(LNREV)과 구전의 크기 (LNMSG), 외생변수는 두 변수를 제외한 나머 지 변수로 설정하였다.

두 식을 2SLS 방식을 사용하여 연립방정식 (Simultaneous Equation)을 통해 추정한 결과 〈표 4-1〉, 〈표 4-2〉와 같은 결과가 나타났다. <식 2>를 고려한 연립방정식 모델의 경우 구 전의 크기(LNMSG)가 개봉 후 1 주차를 제외하 면, 매출에 유의한 영향을 주지 못하고 있고,

\begin{tabular}{|c|c|c|c|c|c|c|c|c|}
\hline \multicolumn{9}{|c|}{$\begin{aligned} L N R E V_{i, t}= & \alpha_{0}+\alpha_{1} L N M S G_{i, t}+\alpha_{2} R A T I N G_{i, t}+\alpha_{3} S C R N_{i, t}+\alpha_{4} C R A T I N G \\
& +\alpha_{5} N E W_{t}+\alpha_{6} A G E_{t}+\epsilon_{i, t}\end{aligned}$} \\
\hline & 1주 & 2주 & 3주 & 4주 & 5주 & 6주 & 7주 & 8주 \\
\hline \multirow{2}{*}{$\begin{array}{l}\text { CONST } \\
\text { 상수항 }\end{array}$} & 17.99 & 19.47 & 18.42 & 16.04 & 15.1 & 14.19 & 12.62 & 12.51 \\
\hline & $0.00 * *$ & $0.00 * *$ & $0.00 * *$ & $0.00 * *$ & $0.00 * *$ & $0.00 * *$ & $0.00 * *$ & $0.00 * *$ \\
\hline \multirow{2}{*}{$\begin{array}{l}\text { LNMSG } \\
\text { 구전크기 }\end{array}$} & 0.36 & 0.07 & -0.06 & -0.22 & -0.36 & -0.66 & 0.00 & 0.15 \\
\hline & $0.00 * *$ & 0.43 & 0.63 & 0.45 & 0.38 & 0.13 & 0.99 & 0.67 \\
\hline \multirow{2}{*}{$\begin{array}{l}\text { RATING } \\
\text { 구전방향 }\end{array}$} & 0.03 & 0.07 & 0.16 & 0.27 & 0.26 & 0.39 & 0.21 & 0.18 \\
\hline & $0.05 *$ & $0.00 * *$ & $0.00 * *$ & $0.00 * *$ & $0.00 * *$ & $0.00 * *$ & $0.01 * *$ & $0.07 *$ \\
\hline \multirow{2}{*}{$\begin{array}{l}\mathrm{SCRN} \\
\text { 개봉관수 }\end{array}$} & 0.00 & 0.01 & 0.01 & 0.02 & 0.03 & 0.05 & 0.05 & 0.04 \\
\hline & $0.00 * *$ & $0.00 * *$ & $0.00 * *$ & $0.00 * *$ & $0.00 * *$ & $0.00 * *$ & $0.00 * *$ & $0.00 * *$ \\
\hline \multirow{2}{*}{$\begin{array}{l}\text { CRATING } \\
\text { 전문가평점 }\end{array}$} & -0.06 & -0.04 & -0.05 & -0.08 & -0.04 & 0.03 & 0.04 & -0.02 \\
\hline & $0.00 * *$ & $0.00 * *$ & $0.01 * *$ & $0.02 * *$ & 0.3 & 0.58 & 0.49 & 0.71 \\
\hline \multirow{2}{*}{$\begin{array}{c}\mathrm{NEW} \\
10 \text { 위권내 } \\
\mathrm{t} \text { 주 개봉작수 }\end{array}$} & -0.03 & -0.11 & -0.11 & -0.05 & -0.06 & -0.01 & -0.01 & -0.06 \\
\hline & 0.22 & $0.00 * *$ & $0.00 * *$ & 0.52 & 0.59 & 0.93 & 0.95 & 0.72 \\
\hline \multirow{2}{*}{$\begin{array}{c}\text { AGE } \\
\text { 10위권내 영화 } \\
\text { 평균상영기간 }\end{array}$} & 0.06 & -0.11 & -0.2 & -0.05 & 0.08 & -0.05 & 0.11 & 0.29 \\
\hline & 0.22 & $0.02 * *$ & $0.00 * *$ & 0.69 & 0.64 & 0.82 & 0.68 & 0.31 \\
\hline
\end{tabular}
구전의 방향성은 1 번의 통계분석과 동일하게

〈표 4-1〉 구전과 매출 간 연립방정식(종속변수: 매출액)

$*: \mathrm{p}<0.1, * *<\mathrm{p}<0.05$ 
〈표 4-2〉 구전과 매출 간 연립방정식(종속변수: 구전의 크기)

\begin{tabular}{|c|c|c|c|c|c|c|c|c|}
\hline \multicolumn{9}{|c|}{$\begin{aligned} L_{N M S G_{i, t}=} & \beta_{0}+\beta_{1} \text { LNREV }_{i, t}+\beta_{2} \text { STAR }_{i}+\beta_{3} \text { GCOMEDY }_{i}+\beta_{4} \text { GACTION }_{i} \\
& +\beta_{5} \text { GSF }_{i}+\beta_{6} \text { CRATING }_{i}+\beta_{7} D P G_{i}+\beta_{8} D R_{i}+\epsilon_{t}\end{aligned}$} \\
\hline & 1주 & 2주 & 3주 & 4주 & 5주 & 6주 & 7주 & 8주 \\
\hline \multirow{2}{*}{$\begin{array}{l}\text { CONST } \\
\text { 상수항 }\end{array}$} & -15.9 & -16.02 & -11.15 & -5.8 & -4.27 & -3.64 & -3.19 & -2.33 \\
\hline & $0.00 * *$ & $0.00 * *$ & $0.00 * *$ & $0.00 * *$ & $0.00 * *$ & $0.00 * *$ & $0.00 * *$ & $0.00 * *$ \\
\hline \multirow{2}{*}{$\begin{array}{l}\mathrm{LNREV} \\
\text { 매출 }\end{array}$} & 1.02 & 1.02 & 0.78 & 0.52 & 0.45 & 0.41 & 0.38 & 0.33 \\
\hline & $0.00 * *$ & $0.00 * *$ & $0.00 * *$ & $0.00 * *$ & $0.00 * *$ & $0.00 * *$ & $0.00 * *$ & $0.00 * *$ \\
\hline \multirow{2}{*}{$\begin{array}{l}\text { STAR } \\
\text { 스타출연여부 }\end{array}$} & -0.12 & -0.1 & -0.06 & -0.11 & -0.09 & -0.09 & -0.16 & 0.01 \\
\hline & 0.17 & 0.23 & 0.48 & 0.33 & 0.47 & 0.54 & 0.32 & 0.97 \\
\hline \multirow{2}{*}{$\begin{array}{l}\mathrm{GCOMEDY} \\
\text { 장르-코미디 }\end{array}$} & -0.37 & -0.38 & -0.39 & -0.36 & -0.38 & -0.65 & -0.32 & -0.64 \\
\hline & $0.00 * *$ & $0.00 * *$ & $0.00 * *$ & $0.00 * *$ & $0.00 * *$ & $0.00 * *$ & $0.05 *$ & $0.00 * *$ \\
\hline \multirow{2}{*}{$\begin{array}{l}\mathrm{GACTION} \\
\text { 장르-액션 }\end{array}$} & -0.25 & -0.33 & -0.29 & -0.07 & 0.04 & 0.13 & 0.46 & 0.42 \\
\hline & $0.00 * *$ & $0.00 * *$ & $0.00 * *$ & 0.52 & 0.75 & 0.36 & $0.01 * *$ & 0.05* \\
\hline \multirow{2}{*}{$\begin{array}{l}\mathrm{GSF} \\
\text { 장르-SF }\end{array}$} & 0.04 & 0.09 & 0.14 & 0.22 & 0.23 & 0.39 & 0.3 & 0.47 \\
\hline & 0.75 & 0.47 & 0.29 & 0.19 & 0.22 & 0.06* & 0.21 & 0.1 \\
\hline \multirow{2}{*}{$\begin{array}{l}\text { CRATING } \\
\text { 전문가평점 }\end{array}$} & 0.11 & 0.13 & 0.13 & 0.12 & 0.07 & 0.07 & 0.08 & 0.09 \\
\hline & $0.00 * *$ & $0.00 * *$ & $0.00 * *$ & $0.00 * *$ & $0.00 * *$ & $0.00 * *$ & $0.00 * *$ & $0.00 * *$ \\
\hline \multirow{2}{*}{$\begin{array}{l}\mathrm{DPG} \\
\text { 전체관람가 }\end{array}$} & -0.31 & -0.37 & -0.5 & -0.6 & -0.59 & -0.58 & -0.43 & -0.29 \\
\hline & $0.00 * *$ & $0.00 * *$ & $0.00 * *$ & $0.00 * *$ & $0.00 * *$ & $0.00 * *$ & $0.02 * *$ & 0.17 \\
\hline \multirow{2}{*}{$\begin{array}{c}\mathrm{DR} \\
\text { 18세 } \uparrow \text { 관람가 }\end{array}$} & -0.01 & 0.09 & 0.03 & -0.04 & 0.08 & 0.01 & 0.16 & 0.01 \\
\hline & 0.91 & 0.32 & 0.77 & 0.73 & 0.61 & 0.97 & 0.44 & 0.97 \\
\hline
\end{tabular}

$*: \mathrm{p}<0.1, * *<\mathrm{p}<0.05$

매출에 양 $(+)$ 의 영향을 주고 있다. 이는 국내 영화 관람객의 경우 개봉 후 1 주차에는 영화를 보기 전 영화 정보 사이트의 별점과 구전의 크 기를 모두 이용하지만, 그 이후부터 영화 관람 시 구전의 크기보다 타인의 평가인 방향성을 기준으로 삼는 것을 의미한다. 이는 첫 번째 분 석에서 나타난 만큼 한국의 관객들은 타인의 영화평에 대한 부분을 서양의 관객보다 상대적 으로 중요시 한다는 것을 의미한다.

영화의 경쟁변수인 $\mathrm{t}$ 주에 개봉한 영화중 10 위권 이내에 속하는 영화의 수(NEW)와 $t$ 주에 10 위권 이내에 속한 영화의 평균 영화기간의
경우 2 주차와 3 주차에는 통계적으로 유의성을 보이지만 일관적인 모습은 보이지 않음에 따라, 경쟁 변수의 영향력은 크지 않음을 알 수 있다.

개봉관의 수는 매출에 직접적인 영향을 미치 는 변수인 만큼 1 8주까지 매출에 통계적으로 유의한 영향을 주고 있다.

<표 4-2〉는 연립방정식 중 매출이 구전의 크 기에 영향을 주는 <식 2>의 분석결과이다. 매 출변수(LNREV)의 계수가 개봉 후 1 주 8주까 지 유의한 양 $(+)$ 의 값을 가진다. 〈표 4-1>의 구전의 크기 변수(LNMSG)가 유의하지 못했던 것을 감안하면, 구전의 크기는 관객이 영화를

\section{4 한국마케팅저널 제12권 제2호 2010년 7월}


보기위한 기준으로 삼는 변수가 아니라, 영화 관람 후 댓글수가 증가하는 결과적인 변수라고 판단할 수 있다. 이는 구전의 크기가 영화의 매 출에 영향을 미친다는 기존의 결과와 상반된다. 물론, 국가 간 차이로 인해 발생한 문제인 점을 감안하더라도, 국내 영화 산업에서의 구전의 크 기는 영향력이 없다고 볼 수 있다.

전문가 평점의 경우, <표 4-1>에서는 첫 번 째 분석결과와 동일한 방향성과 유의성을 보여 주었다. 즉, 매출이 구전의 크기에 주는 영향을 감안하더라도 관객이 영화 관람 시 전문가 평 점을 신뢰하지 않는다는 부분은 동일하게 나타 났다. 〈표 4-2>에서는 전문가 평점이 구전의 크기에 양(+)의 영향을 미치는 것으로 나타났 다. 전문가 평점이 높은 영화의 경우 관객들이
그만큼 많은 댓글들을 작성하는 것을 의미한다. 전문가 평점이 높을 경우 영화를 관람한 관객 들은 평론가들과 자신들의 영화에 대한 의견의 차이를 발견하고 이러한 부분에 대해 온라인 댓글을 통해 본인들의 의견을 나타내는 경우가 많다고 해석할 수 있다.

위의 두 가지 분석을 이용한 결과를 기존의 모델과 함께 〈표 5>를 통해 제시하였다. 1)은 기존 연구결과에 대한 요약을 나타내고, 2)는 기존 연구결과에 국내 영화데이터를 사용한 결 과를 보여주고 있으며, 3)은 매출이 구전의 크 기에 미치는 영향을 감안한 연립방정식 모형의 결과에 대해 설명하고 있다. 구전 변수에 대한 각 모델간의 차이를 정리하면, 1)에서 2)로 데 이터를 변형시켰을 때, 방향성이 유의한 변수가

〈표 5〉 매출과 구전과의 관계 모델의 차이점 분석

\begin{tabular}{|c|c|c|c|}
\hline & 1) Liu(2006) & $\begin{array}{c}\text { 2) } \operatorname{Liu}(2006) \text { 과 } \\
\text { 동일모델(국내데이터사용) }\end{array}$ & 3) Simultaneous Equation 사용 \\
\hline \multirow{3}{*}{ 모델 } & \multicolumn{3}{|c|}{ 1) $L N R E V_{i, t}=\beta_{0}+\beta_{1} L N M S G_{i, t-1}+\beta_{2} R_{A T I N G} G_{i, t-1}+\beta_{3} S C R N_{i, t}+\beta_{4} C R A T I N G_{i}+\beta_{5} N E W_{t}+\beta_{6} A G E_{t}+\epsilon_{i, t}$} \\
\hline & \multicolumn{3}{|c|}{ 2) $L N R E V_{i, t}=\alpha_{0}+\alpha_{1} L N M S G_{i, t}+\alpha_{2} R A T I N G_{i, t}+\alpha_{3} S C R N_{i, t}+\alpha_{4} C R A T I N G+\alpha_{5} N E W_{t}+\alpha_{6} A G E_{t}+\epsilon_{i, t}$} \\
\hline & \multicolumn{3}{|c|}{ 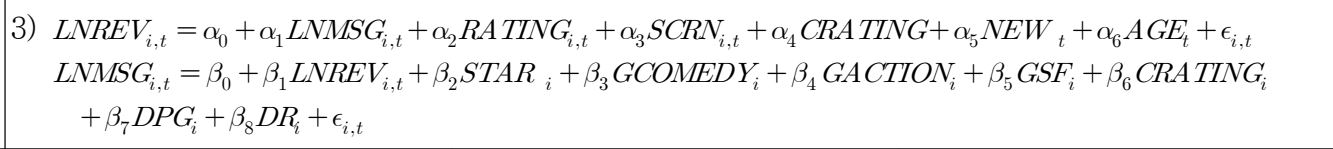 } \\
\hline DATA & $\begin{array}{l}\text { Yahoo Movie } \\
\text { 수집기간: } 5 \text { 개월 } \\
\text { 영화 수/구전 수: } 40 / 12,136\end{array}$ & $\begin{array}{c}\text { 네이버 영화 } \\
\text { 수집기간: } 36 \text { 개월 } \\
\text { 영화 수/구전 수: } 439 / 746,282\end{array}$ & 2)와 동일 \\
\hline $\begin{array}{l}\text { 가설의 } \\
\text { 차이점 }\end{array}$ & $\begin{array}{l}\text { 구전의 크기와 방향성이 매출에 } \\
\text { 일방적인 영향을 준다고 가정 }\end{array}$ & 1)과 동일 & $\begin{array}{l}\text { 구전의 크기와 매출이 상호간 동 } \\
\text { 시에 영향을 주고받는다고 가정 }\end{array}$ \\
\hline $\begin{array}{l}\text { 결과의 } \\
\text { 차이점 }\end{array}$ & $\begin{array}{l}\text { 구전의 크기는 매출에 영향을 주 } \\
\text { 지만, 구전의 방향성은 영향을 주 } \\
\text { 지 못함 } \\
\text { 전문가 평점의 경우 매출에 양 }(+) \\
\text { 의 영향을 미침 }\end{array}$ & $\begin{array}{l}\text { 구전의 크기와 방향성이 매출에 } \\
\text { 동시에 영향을 미침 } \\
\text { 전문가 평점의 경우 매출에 음(-) } \\
\text { 의 영향을 미침 }\end{array}$ & $\begin{array}{l}\text { 구전의 크기는 개봉 } 2 \text { 주차부터 매 } \\
\text { 출에 영향을 주지 못하고, 구전의 } \\
\text { 방향성만이 매출에 영향을 미침. } \\
\text { 전문가 평점이 구전의 크기에 양 } \\
\text { 의 영향을 미치지만, 매출에는 음 } \\
\text { (-)의 영향을 미침. }\end{array}$ \\
\hline
\end{tabular}


되었다. 이는 영화 관람에 있어서 구전의 방향 성을 받아들임에 있어서 동서양 자아관점의 차 이가 있음을 나타낸다. 2)에서 3)으로 모델을 변형시켰을 때, 구전의 크기가 매출의 원인이 아닌 매출의 결과 변수가 되고, 구전의 방향성 이 여전히 유의한 값을 가짐에 따라, 기존의 구 전의 크기가 매출을 증가 시킨다는 결론은 내 생성을 고려하지 않은 것임을 밝혔다.

\section{$\mathrm{V}$. 결론 및 향후 연구 방향}

기존의 영화 산업 관련 문헌에서는 온라인 구전의 크기는 매출에 영향을 미치지만, 방향성 은 영향을 주지 못하는 것으로 연구되었다(Liu 2006; Duan et al 2005). 하지만, 구전에 의한 영향력은 동양권과 서구권의 차이가 존재하기 때문에, 미국의 데이터를 사용한 기존 연구는 일반화된 이론이라 하기 어렵다. 따라서 국내의 영화 데이터를 사용하여 국가 간 차이를 검증 할 필요가 있다. 또한, 구전의 크기 변수는 단 순히 매출에 일방적인 영향을 주는 변수라고 보기는 힘들다. 매출의 증가는 구전의 증가에 영향을 주게 되고, 구전의 증가는 다시 매출에 영향을 주는 관계를 가진 변수라고 보는 것이 더 정확하다. 구전의 크기와 매출이 상호 영향 을 주는 관계를 고려하지 않을 경우 분석 결과 는 실제와 달라질 수 있기 때문에, 두 변수가 상호 영향을 주는 변수라고 가정하여 연립방정 식 분석을 통해 구전의 크기와 매출과의 관계 를 살펴보았다.

본 연구에서는 다음과 같은 두 가지 분석결
과를 보여주었다. 첫째, 기존의 연구 결과와 동 일한 모델에 국내 데이터를 적용할 경우 구전 의 크기 및 방향성이 동일하게 나타나는지 분 석하였다. 국내 관객들의 경우 영화 관람 시에 구전의 방향성에도 영향을 받는다는 결과가 나 왔고, 이는 서양의 경우 독립 자아관점이 일반 적인 것에 반해 한국(아시아)의 경우 상호 의존 적 자아관점이 더 크기 때문이라고 유추할 수 있다. 즉, 우리나라 관객의 경우 영화 선택에 있어서 타인의 선택과 평가에 영향을 많이 받 기 때문에 일반 관객들의 온라인 영화 평가에 따라 영화 관람 여부가 달라지는 것이다.

둘째, '구전이 매출에 일방적인 영향을 준다.' 는 선행 연구들에서 간과된 '매출이 구전에 미 치는 영향'을 감안했을 때, 구전의 크기와 방 향이 매출에 미치는 영향이 변하지 않는가에 대한 분석이다. 기존의 연구결과와 달리, 구전 의 크기는 매출에 개봉 2주차부터 영향을 주지 못한다고 밝혀졌다. 또한, 매출이 구전의 크기 에 주는 영향은 유의한 양(+)의 값을 가짐에 따라, 국내 영화 관람객의 경우 구전의 크기에 영향을 받아 영화 선택을 하는 것이 아니라, 구 전의 방향성에 따라 결정한다는 사실이 밝혀졌 고, 구전의 크기가 증가하는 것은 매출 증가에 의한 영향임을 알게 되었다.

마지막으로, 전문가 평점은 매출에 음(-)의 영향을 주는 것으로 밝혀져 국내 관객들이 전 문가 평점을 신뢰하지 않는 것으로 나타났다. 이는 일반 관객의 경우 평론가들의 평가가 본 인들이 영화를 평가하는 기준과 반대의 성향을 가진다고 생각하기 때문이다. 국내 평론가들의 경우 흥행성은 높지만 영화의 예술적 가치가 
떨어지는 작품에 대해 낮은 평가를 내리는 경 우가 많고, 관객들이 영화를 선택할 때 전문가 들의 평점과 반대의 방향을 선택하게 만든다.

이러한 결과들은 영화 관련 사이트에서 단순 히 온라인 댓글의 수가 영화매출을 결정하고, 영화의 별점이 관객들에게 고려대상이 되지 않 는다는 다소 납득하기 어려운 기존의 연구들에 대한 해답을 주고 있다. 기존의 연구들은 매출 과 댓글이 동시에 증가하는 현상에 대해, 원인 과 결과를 검증하는 분석을 한 것이 아니라, 구 전이 매출에 영향을 줄 것이라는 가정을 검증 했기 때문에 그러한 결과가 나왔다고 볼 수 있다.

본 연구 결과는 영화 관련 기업의 실무자들 에게 고객 커뮤니케이션 수단으로써 온라인 구 전에 대한 관리가 필요하다는 시사점을 준다. 많은 기업들은 소비자들과의 커뮤니케이션에 많은 액수의 비용을 지불하고 있으며, 전통적인 광고, 프로모션 활동과 같은 매스 커뮤니케이션 들을 이용해 영화에 대한 인지도와 호의적 태 도를 형성시키려 노력하고 있으며, 상당한 효과 를 거둔 것이 사실이다. 하지만, 본 연구에서 밝힌 것처럼 온라인 구전의 방향성은 영화의 개봉부터 종영에 이르는 전 기간에 걸쳐 매출 에 영향력을 주고 있기 때문에 효율성 측면에 서 개봉전의 막대한 비용의 판촉 활동보다 더 나을 수 있다. 이를 위해 시사회 등을 통해 소 비자 의견을 반영하고 구전 커뮤니케이션이 활 발한 집단에 대해 마케팅 역량을 집중하는 것 도 하나의 방법이라고 할 수 있다.

하지만, 이러한 결과들은 국내 영화 데이터에 국한되어 있고, 해외 데이터에도 동일하게 적용
될 수 있는지에 대한 부분은 검증이 필요하다. 전문가 평점의 경우 영화 평론가들의 평이 다 양한 매체에 분산되어 있고, 영화평론가들의 수 가 제한되어 있기 때문에 관람객의 관심을 많 이 받지 못하는 영화의 경우 전문가 영화평의 수가 제한되어 있어, 이 부분에 대한 분석 결과 는 조심스럽게 해석할 필요가 있다. 온라인 댓 글의 경우 평균 별점만 사용되었지만, 같은 별 점의 경우에도 별점의 분산이 다르기 때문에 동일하게 취급하는 데는 문제가 있을 수 있다. 관객층에 따라 구전의 크기와 방향성은 많이 달라질 수 있는 점도 고려하여 추가적인 분석 이 필요하다.

〈논문 접수일: 2009. 11. 02〉 <게재 확정일: 2010. 05. 20>

\section{참고문헌}

김성훈(2003), “제품관여도 및 제품지식에 따른 온라인 구전정보 활용 연구," 광고학연구, 14(1), 257-280.

김해룡, 최현국, 이문규(2004), "인터넷 구전 수용의 영향요인," 한국마케팅학회 추계학

술대회발표논문집, 245-255.

박기운, 옥석재(2008), “포털사이트의 지속사용

의도에 영향을 미치는 요인에 관한 연구,"

정보시스템연구, 17(2), 49-72.

박철순, 이준만, 하 송(2007), "인터넷 포털산 업의 재편 : 네이버의 전략적 혁신," 경영 교육연구, 10(2), 107-129.

성영신, 박진영, 박은아(2002), “온라인 구전정 
보가 영화 관람 의도에 미치는 영향, 광 고연구, 57, 31-52.

신선미(2001), "영화관람의 기대형성 및 평가,

구전에 관한 연구," 석사학위 논문, 아주대 대학원.

양윤, 조문주(2000), “구전 커뮤니케이션이 소 비자 태도변화에 미치는 영향,” 광고학연 구, 11(3), 7-28.

이소민(2005), “영화평이 영화 흥행에 미치는 영향에 관한 연구," 서울대학교 경영학 석 사학위 논문.

이은영(2004), “커뮤니티 특성과 사이트 특성이 온라인 구전의 수용과 확산에 미치는 영향 에 관한 연구," 한국마케팅학회 추계학술 대회 발표논문집, 305-325.

이태민, 박철(2006), "온라인 구전정보의 방향 성과 유형이 구매영향력에 미치는 효과: 한국과 미국의 국제비교," 마케팅연구, 21(1), 29-56.

이현선, 리대용(2004), "구전으로서 온라인 사

용후기 효과에 관한 연구,” 홍보학연구, 8(2), 234-268.

장세영(2007), “온라인 구전이 판매에 미치는

영향,” 서울대학교 경영학 석사학위 논문. 황의록, 김창호(1995), “구전커뮤니케이션에 관 한 문헌 연구,” 광고연구, $26,55-84$.

Arker, D. and J. Myers (1982), Advertising

Management, 2nd ed. EngleWood Cliffs, NJ: Prentice-Hall.

Arndt, J. (1967), "Role of Product-related Conversation in the Diffusion of a New Product," Journal of Marketing Research,
4, 291-295.

Austin, B. and T. Gordon (1987), Movie genres: Toward a conceptualized model and Standardized definitions, Bruce A. Austin ed. Current Research In Film: Audience, Economics and Law, vol. 3. Nordwood, NJ: Ablex Publishing.

Austin, B. (1989), Immediate Seating: A Look at Movie Audiences. Belmont, CA: Wadsworth.

Banerjee, A. (1992), "A Simple Model of Herd Behavior," Quarterly Journal of Economics, 107 (3), 797 - 817.

Basuroy, S., S. Chatterjee, and S. Ravid (2003), "How Critical Are Critical Reviews? The Box Office Effects of Film Critics, Star Power, and Budgets," Journal of Marketing, 67 (October), 103-117.

Bayus, B. (1985), "Word of Mouth: The Indirect Effect of Marketing Efforts," Journal of Advertising Research, 25(3), 31-39.

Beck, U. (1992), Rick Society: Towards a New Modernity, Sage publications.

Bickart, B. and R. Schindler (2002), "Expanding the Scope of Word of Mouth: Consumer-Consumer Information on the Internet," Advances in consumer research, 29, 428-430.

Brown, J. and P. Reingen (1987), "Social Ties and Word-of-Mouth Referral 
Behavior," Journal of Consumer Research, 14 (December), 350 - 362.

Bussiere, D. (2000), "Evidence and implications of Electronic Word-of-Mouth," Developments in marketing science, 23, 321-322.

Chatterjee, P. (2001), "Online Reviews: Do consumers use them?", Advances in Consumer Research, 28, 129-133.

Chen, Y. and J. Xie (2008), "Online Consumer Review: Word-of-Mouth as a New Element of Marketing Communication Mix," Management Science, 54(3), 477-491.

Chevalier, J. and D. Mayzlin (2006), "The Effects of Word of Mouth on Sales: Online Book Reviews," Journal of Marketing Research, 43(August). 345354.

Dellarocas, C. (2003), "The Digitization of Word of Mouth: Promise and Challenges of Online Feedback Mechanisms," Management Science, 49(10), 1407-1424.

Dellarocas, C., N. Awad, and M. Zhang (2004), "Exploring the Value of Online Reviews to Organizations: Implications for Revenue Forecasting and Planning," working paper, MIT Sloan School of Management.

Duan, W., B. Gu, and A. Whinston (2005), "Do Online Reviews Matter? An Empirical Investigation of Panel Data," working paper, Department of Management Science and Information Systems, University of Texas at Austin.

Eliashberg, J., A. Elberse, and M. Leenders (2006), "The Motion Picture Industry: Critical Issues in Practice, Current Research and New Research Directions," Marketing Science, 25(6), 638-661.

Elberse, A. and J. Eliashberg (2003), "Demand and Supply Dynamics for Sequentially Released Products in International Markets: The Case of Motion Pictures," Marketing Science, 22(3), 329-354.

Eliashberg, J. and S. Shugan (1997), "Film Critics: Influencers or Predictors?" Journal of Marketing, 61(April), 68-78. Faber, R. and T. O'Guinn (1984), "Effect of Media Advertising and Other Source on Movie Selection," Journalism Quarterly, 61(2), 371-377.

Godes, D. and D. Mayzlin (2004), "Using Online Conversations to Study Wordof-Mouth Communication," Marketing Science, 23(4), 545 - 560.

Henning-Thurau, T. and G. Walsh (2003), "Electronic word-of-mouth: Motives for and Consequences of Reading Customer Articulations on the Internet," International Journal of Electronic Commerce, 8(2), 51-74.

Henning-Thurau, T., K. Gwinner, G. Walsh, 
and D. Gremler (2004), "Electronic Word-Of-Mouth via Consumer-Opinion Platforms: What Motives Consumers to Articulate Themselves on the Internet?," Journal of Interactive Marketing, 18(1), 38-52.

Hirschman, E. and A. Pieros (1985), "Relationships Among Indicators of Success in Broadway Plays and Motion Pictures," Journal of Cultural Economics, 9(June), 35-63.

Levene, C. (1992), "Marketing Art Films to College Students," working paper, The Wharton School, University of Pennsylvania.

Lin, J.C.C. and H. Lu (2000), "Towards an Understanding of the Behavioural Intention to Use a Web Site," Information Management, 20, 197-208.

Linton, J. and J. Petrovich (1988), The application of the consumer information acquisition approach to movie selection: An exploratory study. In B. A. Austin (Ed.), Current research in film: Audiences, economics, and law (Vol. 4, pp. 24-44). Norwood, NJ: Ablex.

Litman, B. and L. Kohl (1989), "Predicting Financial Success of Motion Pictures: The Early '80s experience," Journal of Media Economics, 2, 35 - 50.

Litman, B. (1983), "Predicting Success of
Theatrical Movies: An Empirical Study," Joumal of Popular Culture, 16(Spring), 159-175.

Liu, Y. (2006), "Word of Mouth for Movies: Its Dynamics and Impact on Box Office Revenue," Journal of Marketing, 70(July), 74-89.

Mahajan, V., E. Muller, and R. Kerin (1984), "Introduction Strategy for New Products with Positive and Negative Word-of-Mouth," Management Science, 30(12), 1389 - 1404.

Markus, H. and S. Kitayama (1991), "Culture and the Self: Implications for Cognition, Emotion, and Motivation," Psychological Review, 98, 224-253.

Mayzlin, D. (2006), "Promotional Chat on the Internet," Marketing Science, 25(2), 155-163.

Mizerski, R. (1982), “An Attribution Explanation of the Disproportionate Influence of Unfavorable Information," Journal of Consumer Research, 9(3), 301-310.

Moon, S., P. Bergey, and D. Lacobucci (2010), "Dynamic Effects Among Movie Ratings, Movie Revenues, and Viewer Satisfaction," Journal of Marketing, 74(Jan), 103-121.

Murray, K. (1991), “A Test of Services Marketing Theory: Consumer Information Acquisition Activities," Journal of 
Marketing, 55 (January), 10-25.

Neelamegham, R. and P. Chintagunta (1999), “A Bayesian Model to Forecast New Product Performance in Domestic and International Markets," Marketing Science, 18(2), 115 - 136.

Ritchins, M. (1983), "Negative Word-ofMouth by Dissatisfied Consumer: A Pilot Study," Journal of Marketing, 47(Winter), 63-79.

Shim, S., A. Eastick, L. Lotz, and P. Warrington (2001), “An Online Prepurchase Intention Model: The Role of Intention to Search," Journal of retailing, 77, 397-416.

Shugan, S. (1995), Service Strategy.

Homewood, IL: Richard D. Irwin.

Silverman, G. (2001), Secrets of Word-of-Mouth Marketing: How to trigger exponential sales through runaway word of mouth. NY: AMACOM.
Taylor, J. (2003), "Word of Mouth Is Where It's At," Brandweek, (June 2), 26.

Trusov, M., R. Bucklin, and K. Pauwels (2009), "Effects of Word-of-Mouth Versus Traditional Marketing: Findings from an Internet Social Networking Site," Journal of Marketing; 73(Sep), 90-102.

Vogel, H. (2001), Entertainment Industry Economics: A Guide for Financial Analysis, 5th ed. Cambridge, UK: Cambridge University Press.

Zaltman, G. and M. Wallendorf (1979), Consumer Behavior: Basic Findings and Management Implication, New York : John Wiley \& Sons Inc.

Zufryden, F. (1996), "Linking Advertising to Box-Office Performance of New Film Release: A Marketing Planning Model," Journal of Advertising Research, 36(4), 29-41. 


\title{
Simultaneous Effect between eWOM and Revenues \\ : Korea Movie Industry*
}

\author{
Bae,Jungho** \\ Shim,Bum Jun*** \\ Kim, Byung-Do****
}

\begin{abstract}
s
Motion pictures are so typical experience goods that consumers tend to look for more credible information. Hence, movie audiences consider movie viewers' reviews more important than the information provided by the film distributor. Recently many portal sites allow consumers to post their reviews and opinions so that other people check the number of consumer reviews and scores before going to the theater.

There are a few previous researches studying the electronic word of mouth(eWOM) effect in the movie industry. They found that the volume of eWOM influenced the revenue of the movie significantly but the valence of eWOM did not affect it much (Liu 2006).

The goal of our research is also to investigate the eWOM effects in general. But our research is different from the previous studies in several aspects.

First, we study the eWOM effect in Korean movie industry. In other words, we would like to check whether we can generalize the results of the previous research across countries. The similar econometric models are applied to Korean movie data that include 746,282 consumer reviews on 439 movies. Our results show that both the valence(RATING) and the volume(LNMSG) of the eWOM influence weekly movie revenues. This result is different from the previous research findings that the volume only influences the revenue. We conjectured that the difference of self construal between Asian and American culture may explain this difference (Kitayama 1991). Asians including Koreans have more

\footnotetext{
* This research was funded by Management Research Center in College of Business Administration, Seoul National University.

** Ph.D. Candidate, College of Business Administration, Seoul National University.

*** Korea Development Bank.

**** Professor, College of Business Administration, Seoul National University.
} 
interdependent self construal than American, so that they are easily affected by other people's thought and suggestion. Hence, the valence of the eWOM affects Koreans' choice of the movie.

$$
\begin{aligned}
L N R E V_{i, t}= & \beta_{0}+\beta_{1} L N M S G_{i, t}+\beta_{2} R A T I N G_{i, t}+\beta_{3} S C R N_{i, t}+\beta_{4} C R A T I N G_{i}+\beta_{5} N E W_{t} \\
& +\beta_{6} A G E_{t}+\epsilon_{i, t}
\end{aligned}
$$

subscript i/t: each movie/week number after the movie open

LNMSG: the number of consumer online review messages(log scale)

RATING: consumer rating on the movie

SCRN: the number of screens

CRATING: critical review rating

NEW: number of new release among the top 10 in week $t$

AGE: average age of the top 10 movies in week $t$

Second, we find the critical defect of the previous eWOM models and, hence, attempt to correct it. The previous eWOM model assumes that the volume of eWOM (LNMSG) is an independent variable affecting the movie revenue (LNREV). However, the revenue can influence the volume of the eWOM. We think that treating the volume of eWOM as an independent variable a priori is too restrictive. In order to remedy this problem, we employed a simultaneous equation in which the movie revenue and the volume of the eWOM can affect each other. That is, our eWOM model assumes that the revenue (LNREV) and the volume of eWOM (LNMSG) have endogenous relationship where they influence each other. The results from this simultaneous equation model showed that the movie revenue and the eWOM volume interact each other. The movie revenue influences the eWOM volume for the entire 8 weeks. The reverse effect is more complex. Both the volume and the valence of eWOM affect the revenue in the first week, but only the volume affect the revenue for the rest of the weeks. In the first week, consumers may be curious about the movie and look for various kinds of information they can trust, so that they use the both the quantity and quality of consumer reviews. But from the second week, the quality of the eWOM only affects the movie revenue, implying that the review ratings are more important than the number of reviews.

Third, our results show that the ratings by professional critics (CRATING) had negative 
effect to the weekly movie revenue (LNREV). Professional critics often give low ratings to the blockbuster movies that do not have much cinematic quality. Experienced audiences who watch the movie for fun do not trust the professionals' ratings and, hence, tend to go for the low-rated movies by them.

$$
\begin{aligned}
\operatorname{LNREV}_{i, t} & =\alpha_{0}+\alpha_{1} \operatorname{LNMSG}_{i, t}+\alpha_{2} \operatorname{RATING}_{i, t}+\alpha_{3} S C R N_{i, t}+\alpha_{4} C R A T I N G \\
& +\alpha_{5} N E W_{t}+\alpha_{6} A G E_{t}+\epsilon_{i, t} \\
& \\
\text { LNMSG }_{i, t} & =\beta_{0}+\beta_{1} \text { LNREV }_{i, t}+\beta_{2} \text { STAR }_{i}+\beta_{3} \text { GCOMEDY }_{i}+\beta_{4} \text { GACTION }_{i} \\
& +\beta_{5} \text { GSF }_{i}+\beta_{6} \text { CRATING }_{i}+\beta_{7} D P G_{i}+\beta_{8} D R_{i}+\epsilon_{i, t}
\end{aligned}
$$

STAR: indicator whether the movie has major stars

GCOMEDY/GSF/GACTION: dummy for movie genre (comedy/SF/action)

DPG/DR: dummy for PG/R

LNREV,LNMSG: endogenous variable

In summary, applied to the Korean movie ratings data and employing a simultaneous model, our results are different from the previous eWOM studies: 1) Koreans (or Asians) care about the others' evaluation quality more than quantity, 2) The volume of eWOM is not the cause but the result of the revenue, 3) Professional reviews can give the negative effect to the movie revenue. 
〈Table 1〉 Differences between three models

\begin{tabular}{|c|c|c|c|}
\hline & 1) $\mathrm{Liu}(2006)$ & $\begin{array}{l}\text { 2) The same model as 1) } \\
\text { (Korea Movie Data) }\end{array}$ & $\begin{array}{l}\text { 3) The Simultaneous } \\
\text { Equation Model }\end{array}$ \\
\hline \multirow{3}{*}{ Model } & \multicolumn{3}{|c|}{ 1) $\begin{aligned} L_{N R E V_{i, t}}=\beta_{0}+\beta_{1} L N M S G_{i, t-1}+\beta_{2} R A T I N G_{i, t-1}+\beta_{3} S C R N_{i, t}+\beta_{4} C R A T I N G_{i} \\
+\beta_{5} N E W_{t}+\beta_{6} A G E_{t}+\epsilon_{i, t}\end{aligned}$} \\
\hline & \multicolumn{3}{|c|}{ 2) $\begin{aligned} & L N R E V_{i, t}=\alpha_{0}+\alpha_{1} L N M S G_{i, t}+\alpha_{2} R A T I N G_{i, t}+\alpha_{3} S C R N_{i, t}+\alpha_{4} C R A T I N G \\
& +\alpha_{5} N E W_{t}+\alpha_{6} A G E_{t}+\epsilon_{i, t}\end{aligned}$} \\
\hline & \multicolumn{3}{|c|}{ 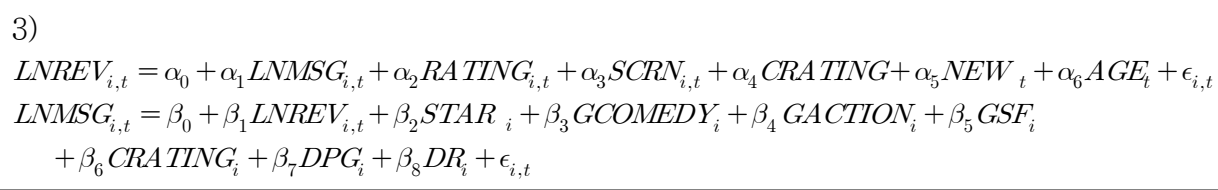 } \\
\hline DATA & $\begin{array}{l}\text { Yahoo Movie } \\
\text { Data collecting: } 5 \text { months } \\
\text { the number of } \\
\text { movie/eWOM } \\
: 40 / 12,136\end{array}$ & $\begin{array}{c}\text { Naver Movie Sites } \\
\text { (The biggest movie sites in } \\
\text { Korea) } \\
\text { Data collecting: } 36 \text { months } \\
\text { the number of } \\
\text { movie/eWOM } \\
: 439 / 746,282\end{array}$ & The same as 2) \\
\hline $\begin{array}{l}\text { Difference in } \\
\text { Hypothesis }\end{array}$ & $\begin{array}{l}\text { The volume and valence of } \\
\text { eWOM influence the revenue }\end{array}$ & The same as 1) & $\begin{array}{l}\text { The volume of eWOM and } \\
\text { the revenue affect each } \\
\text { other at the same time }\end{array}$ \\
\hline $\begin{array}{l}\text { Difference in } \\
\quad \text { Result }\end{array}$ & $\begin{array}{l}\text { The volume coefficient is } \\
\text { significantly positive. } \\
\text { The valence coefficient is } \\
\text { not significant. } \\
\text { Critics has positive effect } \\
\text { on the revenue. }\end{array}$ & $\begin{array}{l}\text { Both the volume and the } \\
\text { valence coefficient is } \\
\text { significantly positive } \\
\text { Critics has negative effect } \\
\text { on the revenue. }\end{array}$ & $\begin{array}{l}\text { The volume coefficient is } \\
\text { not significant (except the } \\
\text { 1st week) } \\
\text { The revenue has positive } \\
\text { effect on the volume of the } \\
\text { eWOM } \\
\text { Critics has negative effect } \\
\text { on the revenue and } \\
\text { positive effect on the } \\
\text { volume of the eWOM }\end{array}$ \\
\hline
\end{tabular}

Key words: eWom, movie revenue, movie review, internet portal site, simultaneous equation 